\title{
19: 47079107-47103444
}

National Cancer Institute

\section{Source}

National Cancer Institute. 19:47079107-47103444. NCI Thesaurus. Code C41715.

Physical location of ARHGEF1_Gene 